\title{
Agronomic Performance of Soybean With Seeds Treated With an Algae Extract Base Biostimulant
}

\author{
Gabriel Bressiani Melo ${ }^{1}$, Alessandro Guerra da Silva ${ }^{2}$, Adriano Perin ${ }^{1}$, Guilherme Braga Pereira Braz ${ }^{2}$ \\ $\&$ Christiano Lima Lobo de Andrade ${ }^{1}$ \\ ${ }^{1}$ Instituto Federal Goiano, Rio Verde, Goiás, Brazil \\ ${ }^{2}$ Universidade de Rio Verde, Rio Verde, Goiás, Brazil \\ Correspondence: Gabriel Bressiani Melo, Instituto Federal Goiano, Rio Verde, Goiás, Brazil. Tel: \\ 55-64-99210-5659. E-mail: gabremelo@gmail.com
}

Received: October 11, 2020

Accepted: November 21, 2020

Online Published: December 15, 2020

doi:10.5539/jas.v13n1p147

URL: https://doi.org/10.5539/jas.v13n1p147

\begin{abstract}
The use of biostimulants in the treatment of soybean seeds can provide beneficial effects on the crop due to the synergism between the organic components present in products from natural compounds. Due to the scarcity of results of research on biostimulants in the treatment of soybean seeds, the objective of this study was to evaluate the effects of doses of a biostimulant in the treatment of seeds, on agronomic characteristics, productivity components and profitability of soybean culture. Therefore, two experiments were carried out in the field in the 2016/17 and 2017/18 harvests, using a randomized block design with six replications and four treatments referring to doses of $0.00 ; 0.05 ; 0.10$; and $0.15 \mathrm{~L} 100 \mathrm{~kg} \mathrm{seeds}^{-1}$. The agronomic characteristics of soybeans, grain yield and profitability of using the biostimulant were evaluated. From the obtained results, it can be seen that the dose of $0.15 \mathrm{~L} 100 \mathrm{~kg}$ seeds $^{-1}$ provided greater profitability in both harvests. In addition, doses above $0.12 \mathrm{~L} 100 \mathrm{~kg} \mathrm{seed}^{-1}$ provide higher grain yields and a higher grain mass, in addition to other productivity components.
\end{abstract}

Keywords: Ascophyllum nodosum, biostimulation, Glycine max L., grain yield, phytohormones, profitability

\section{Introduction}

The increase in national soy production in recent years is directly related to the adoption of new technologies in crop management. In contrast, there is an increase in crop production costs, which results in profitability reduction, even with an increase in grain productivity (Embrapa, 2017). In order to increase profitability in the commercial exploration of soybeans, many producers have been looking for technologies that make it possible to increase productivity and have a good cost to benefit ratio.

In this context, biostimulants appear as an interesting option for agricultural systems, due to the potential to provide productivity increases, coupled with their low cost when compared to other agricultural inputs. These factors have made this class of inputs increasingly more adopted in soybean crops (Santini et al., 2015).

When used in seed treatment, biostimulants can increase germination rate and seedling emergence, thus plant standing, essential for obtaining a larger productivity (Carvalho, 2013). In addition, the adoption of these products in seed treatment, when compared to foliar application, reduces the number of operations to be carried out after the emergence of the crop. As a consequence, there is a reduction in the plant kneading in the crop and in soil compaction (Ferreira et al., 2020), a reduction in the risk of losses due to spraying (Contiero et al., 2016), beside saving machine, labor and time to spray the crop.

However, despite the wide dissemination of biostimulants of synthetic origin (Albrecht et al., 2011; Santini et al., 2015; Yakhin et al., 2017), research studies have demonstrated benefits from the use of biostimulants derived from natural compounds, especially those based on seaweed extract of Ascophyllum nodosum in soybean crops (Carvalho, 2013; Araújo, 2016; Andrade et al., 2020). It is known that this seaweed survives under variable conditions of temperature and tidal waves, an environment that allows the accumulation of several organic compounds such as amino acids, phytohormones, polyphenols, betaines, polysaccharides, fatty acids, steroids and polyamines, in addition to macro and micronutrients in which they cause beneficial effects when applied to agricultural crops (Craigie, 2011). 
In seed treatment, the use of products based on $A$. nodosum extract has promoted improvements in germination and seedling establishment, in mobilization, absorption and partitioning of nutrients, in roots emission, in greater growth of the shoot and chlorophyll content. Thus, these effects confer tolerance to biotic and abiotic stresses as well, which has favored productivity increases (Sharma et al., 2014).

Despite being considered a promising technology, literature is scarce in regard to the use of biostimulants for seed treatment on the agronomic characteristics of soybean grown in cerrado conditions. In this sense, the present study aimed to evaluate the effects of doses of a biostimulant, based on A. nodosum in seed treatment, on the agronomic characteristics, on the productivity components and on the profitability of the soybean crop grown in cerrado edaphoclimatic conditions.

\section{Materials and Methods}

The field experiment was installed in the municipality of Montividiu, Goiás, in agricultural years of 2016/17 $\left(17^{\circ} 31.051^{\prime} \mathrm{S} ; 051^{\circ} 12.933^{\prime} \mathrm{W}\right.$; at an altitude of $\left.890 \mathrm{~m}\right)$ and $2017 / 18\left(17^{\circ} 31.312^{\prime} \mathrm{S} ; 51^{\circ} 13.275^{\prime} \mathrm{W}\right.$; at an elevation of $876 \mathrm{~m}$ asl.). The region's climate is classified as Aw (tropical climate with dry winter season) according to the Köppen classification. Precipitation and average air temperature data during the tests are shown in Figure 1.

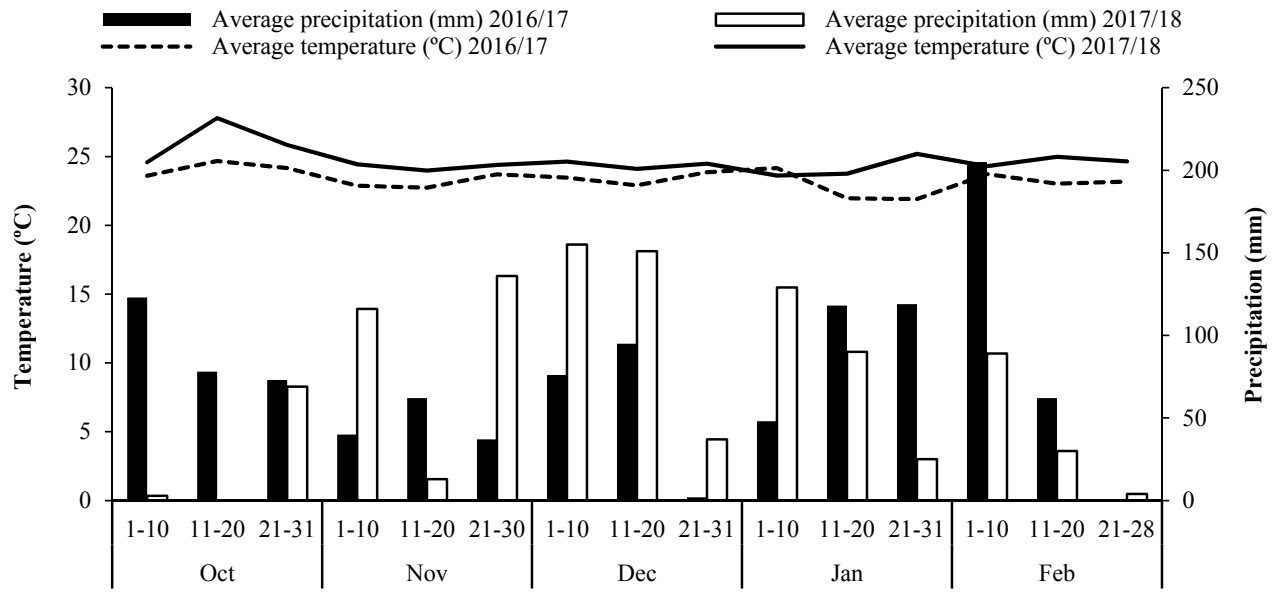

Figure 1. Average values of precipitation $(\mathrm{mm})$ and average air temperature $\left({ }^{\circ} \mathrm{C}\right)$ during the conduction of the tests. Montividiu-GO, 2016/17 and 2017/18 harvests

The soil of experimental area is a Red Latosol, and it was cultivated under no-tillage for twenty years, where corn rotated with soybean. In both harvests, at sowing, soil samplings were taken at depths of 0 to 10 and 10 to $20 \mathrm{~cm}$ and interpreted according to Ribeiro et al. (1999) (Tables 1 and 2).

Table 1. Classification of soil attributes in the experimental area. Montividiu-GO, 2016/17 harvest

\begin{tabular}{|c|c|c|c|c|c|c|c|c|c|c|c|c|c|c|c|}
\hline Depth & $\mathrm{Ca}$ & $\mathrm{Mg}$ & K & $\mathrm{Al}$ & $\mathrm{H}+\mathrm{Al}$ & SB & CEC & $\mathrm{pH}$ & $P$ & Base Sat. & Alum. Sat. & O.M. & Clay & Silt & Sand \\
\hline & ------- & ------ & ----- c & $\mathrm{cmol}_{\mathrm{c}} \mathrm{dm}$ & (3.---- & - & ---- & $\mathrm{CaCl}_{2}$ & $\mathrm{mg} \mathrm{dm^{-3 }}$ & $\mathrm{V} \%$ & $\mathrm{~m} \%$ & $\mathrm{~g} \mathrm{dm}^{-3}$ & ---- & $--\%$ & ----- \\
\hline $0-10 \mathrm{~cm}$ & $1.7 \mathrm{M}$ & $0.5 \mathrm{M}$ & $0.3 \mathrm{H}$ & $0.1 \mathrm{VL}$ & $4.1 \mathrm{H}$ & $2.5 \mathrm{M}$ & $6.7 \mathrm{M}$ & $4.8 \mathrm{M}$ & $6.8 \mathrm{~L}$ & $38 \mathrm{~L}$ & $4.5 \mathrm{VL}$ & $42 \mathrm{H}$ & 47 & 8 & 45 \\
\hline $10-20 \mathrm{~cm}$ & $1.2 \mathrm{~L}$ & $0.3 \mathrm{~L}$ & $0.2 \mathrm{H}$ & $0.2 \mathrm{~L}$ & $3.6 \mathrm{H}$ & $1.7 \mathrm{~L}$ & $5.3 \mathrm{M}$ & $4.5 \mathrm{~L}$ & $4.9 \mathrm{~L}$ & $32 \mathrm{~L}$ & $12 \mathrm{VL}$ & $37 \mathrm{M}$ & 47 & 8 & 45 \\
\hline
\end{tabular}

Note. Soil attributes classified as very high (VH), high (H), medium (M), low (L) and very low (VL).

Table 2. Classification of soil attributes in the experimental area. Montividiu-GO, 2017/18 harvest

\begin{tabular}{|c|c|c|c|c|c|c|c|c|c|c|c|c|c|c|c|}
\hline Depth & $\mathrm{Ca}$ & $\mathrm{Mg}$ & K & $\mathrm{Al}$ & $\mathrm{H}+\mathrm{Al}$ & SB & CEC & $\mathrm{pH}$ & $\mathrm{P}$ & Base Sat. & Alum. Sat & O.M. & Clay & Silt & Sand \\
\hline & $-\ldots$ & ----- & -... & $\mathrm{cmol}$ & $m^{-3}=$ & - & -------- & $\mathrm{CaCl}_{2}$ & $\mathrm{mg} \mathrm{dm}^{-3}$ & V\% & $\mathrm{m} \%$ & $\mathrm{~g} \mathrm{dm}^{-3}$ & ----- & $--\%$ & ------- \\
\hline $0-10 \mathrm{~cm}$ & 4.5 & 1 & 0.3 & 0.3 & 3.5 & 5.7 & 9.3 & 4.3 & 26 & 62 & 4.2 & 46 & 54 & 10 & 36 \\
\hline $10-20 \mathrm{~cm}$ & 1.8 & 0.3 & 0.2 & 0.3 & 4.7 & 2.3 & 7 & 3.9 & 8.9 & 33 & 11 & 32 & 57 & 8 & 35 \\
\hline
\end{tabular}

Note. Soil attributes classified as very high (VH), high (H), medium (M), low (L) and very low (VL). 
In both years, a randomized block design was adopted, with four treatments and six repetitions. The treatments corresponded to the use of increasing doses of the biostimulant $\operatorname{Radifarm}^{\circledR}(0.00 ; 0.05 ; 0.10$; and $0.15 \mathrm{~L} 100 \mathrm{~kg}$ seeds $^{-1}$ ) via seed treatment. This product is derived from natural compounds, having as ingredients urea, potassium acetate, zinc chelate, vinasse and algae extract (A. nodosum). Its composition is characterized by containing $10.0 \% \mathrm{C}_{\text {org }}, 8.0 \% \mathrm{~K}_{2} \mathrm{O}, 3.0 \% \mathrm{~N}, 0.1 \% \mathrm{Zn}$ and $78.9 \%$ inert ingredients (Valagro, 2018). The experimental plots contained five lines $6.0 \mathrm{~m}$ long, spaced $0.5 \mathrm{~m}$ apart. The usable area was obtained taking into account the two central lines, disregarding $0.5 \mathrm{~m}$ from each end, thus presenting $5.0 \mathrm{~m}^{2}$.

For the first harvest, the cultivar TMG 7062 IPRO $^{\circledR}$ (maturation group 6.2 and semi-determined growth habit) was planted at the rate of 260000 seeds $\mathrm{ha}^{-1}$. For the second harvest, due to seed availability in the market and the representativeness of cultivation in the region, the cultivar M7110 IPRO ${ }^{\circledR}$ (maturation group 6.8 and indeterminate growth habit) was planted at the reate of 440000 seeds ha ${ }^{-1}$.

The biostimulant was applied via seed treatmentin samples of $4.0 \mathrm{~kg}$ of seeds, which were packed in plastic bags for homogenization and drying. Sowing was carried out mechanically using a five-row pneumatic seeder. This operation was carried out after the rainy season in the region, which occurred on October 21, 2016 and October 30,2017 , for the first and second year of experiment, respectively. In order not to affect the development of plants, phytosanitary management (control of weeds, pests and diseases) was carried out according to the needs of the crop.

The harvest took place on February 16, 2017 (118 days after emergence-DAE) for the first harvest, while on the second it was carried out on February 17, 2018 (105 DAE). of the following measuremnts were taken: grain yield (harvesting of the plants, threshing the pods and weighing the grains with humidity correction to $13 \%$ ), mass of one thousand grains (counting and subsequent weighing of the thousand grains from the productivity sample, with humidity correction to $13 \%$ ), number of grains per plant (count of the number of grains in five plants chosen at random), number of pods on the main, secondary and total stems (count of the number of pods on the main and secondary stems, as well as the number of total pods on five plants chosen at random), number of branches (counting the number of secondary stems on five plants chosen at random), plant population (counting the number of plants) and plant height and insertion height of the first pod (measurement of the neck to the end of the last trefoil and insertion of the first pod, respectively, in five plants chosen at random).

To determine the profitability of using the biostimulant (Equation 1), the value of the $60 \mathrm{~kg}$ bag of soybeans of U\$ 21.69 and U\$ 18.57 for the 2016/17 and 2017/18 harvests was taken into account, respectively. The cost of applying the Radifarm ${ }^{\circledR}$ biostimulant in the doses of the respective treatments was also considered, when the trial was implemented (U\$ 30.80 and U\$ 33.23 for the 2016/17 and 2017/18 harvests, respectively). The values used to make the profitability of using the biostimulant were obtained from retailers located in the city of Rio Verde, Goiás.

$$
\text { RENT }=\frac{\text { PROD Tratam(i) }- \text { PROD Test }}{60} \times \text { Value of soybean per bag }
$$

Where, PROD Treat (i): grain yield in each dose of the biostimulant; PROD Test: grain yield of the control treatment (dose $0.00 \mathrm{~L} 100 \mathrm{~kg} \mathrm{seeds}^{-1}$ ).

All data were subjected to analysis of variance using the $\mathrm{F}$ test (except for the profitability variable). When significance was found, polynomial regression analysis was used to compare treatment averages.

\section{Results}

\subsection{Harvest 2016/17}

The results obtained in the first harvest allowed to verify the effects of the doses of the biostimulant for grain productivity and mass of a thousand grains (Table 3). 
Table 3. Summary of the analysis of variance and average values of grain yield (PROD), thousand grain mass (MMG), number of grains per plant (NGP), pods on the main (NVP), secondary (NVS) and total (NVT), number of branches (RAM), population (POP) and plant heights (AP) and insertion of the first pod (AIV) of the soybean seed treatment trial with algae extract biostimulant. Montividiu-GO, 2016/17 harvest

\begin{tabular}{|c|c|c|c|c|c|c|c|}
\hline Variation sources & GL & PROD $\left(\mathrm{kg} \mathrm{ha}^{-1}\right)$ & MMG (g) & NGP & NVP & NVS & NVT \\
\hline Blocs & 5 & ns & ns & ns & ns & ns & ns \\
\hline Treatments & 3 & $*$ & $*$ & ns & ns & ns & ns \\
\hline Variation Coef. $(\%)$ & & 5.12 & 2.88 & 15.32 & 51.19 & 17.30 & 27.11 \\
\hline Means & & 5.000 & 197.0 & 113.0 & 18.0 & 32.0 & 50.0 \\
\hline Reg. Linear & 1 & $*\left(\mathrm{R}^{2} 0.35\right)$ & $\mathrm{n}^{\mathrm{n}}\left(\mathrm{R}^{2} 0.08\right)$ & $\mathrm{ns}\left(\mathrm{R}^{2} 0.64\right)$ & ns $\left(\mathrm{R}^{2} 0.00\right)$ & $\mathrm{ns}\left(\mathrm{R}^{2} 0.08\right)$ & $\mathrm{ns}^{-}\left(\mathrm{R}^{2} 0.01\right)$ \\
\hline Reg. Quadratic & 1 & $*\left(\mathrm{R}^{2} 0.99\right)$ & $*\left(\mathrm{R}^{2} 0.82\right)$ & ${ }^{n s}\left(R^{2} 0.65\right)$ & ${ }^{\mathrm{ns}}\left(\mathrm{R}^{2} 0.00\right)$ & ${ }^{\mathrm{ns}}\left(\mathrm{R}^{2} 0.34\right)$ & ${ }^{\mathrm{ns}}\left(\mathrm{R}^{2} 0.08\right)$ \\
\hline Variation sources & GL & RAM & \multicolumn{2}{|c|}{ POP (plants ha ${ }^{-1}$ ) } & $\mathrm{AP}(\mathrm{cm})$ & \multicolumn{2}{|c|}{ AIV $(\mathrm{cm})$} \\
\hline Blocs & 5 & ns & \multicolumn{2}{|c|}{ ns } & $*$ & \multicolumn{2}{|l|}{$*$} \\
\hline Treatments & 3 & ns & \multicolumn{2}{|l|}{ ns } & ns & \multicolumn{2}{|l|}{ ns } \\
\hline Variation Coef. $(\%)$ & & 31.64 & \multicolumn{2}{|l|}{13.35} & 4.84 & \multicolumn{2}{|l|}{6.44} \\
\hline Means & & 3.0 & \multicolumn{2}{|l|}{228.021} & 72.2 & \multicolumn{2}{|l|}{11.9} \\
\hline Reg. Linear & 1 & ${ }^{n}\left(R^{2} 0.05\right)$ & \multicolumn{2}{|c|}{${ }^{\mathrm{ns}}\left(\mathrm{R}^{2} 0.05\right)$} & ${ }^{\mathrm{ns}}\left(\mathrm{R}^{2} 0.27\right)$ & \multicolumn{2}{|c|}{$\mathrm{ns}\left(\mathrm{R}^{2} 0.85\right)$} \\
\hline Reg. Quadratic & 1 & ${ }^{n s}\left(R^{2} 0.05\right)$ & \multicolumn{2}{|c|}{${ }^{\mathrm{ns}}\left(\mathrm{R}^{2} 0.79\right)$} & ${ }^{n s}\left(R^{2} 0.77\right)$ & \multicolumn{2}{|c|}{${ }^{\mathrm{ns}}\left(\mathrm{R}^{2} 0.88\right)$} \\
\hline
\end{tabular}

Note. ${ }^{*}$ and ns: significant at 5\% probability and not significant, respectively, by the F test. GL: degrees of freedom.

Increases in the productivity of soybeans could be seen due to the effects of the biostimulant in doses greater than $0.58 \mathrm{~L} 100 \mathrm{~kg} \mathrm{seeds}^{-1}$ (Figure 2). It is noteworthy that doses above $0.12 \mathrm{~L} 100 \mathrm{~kg}$ seeds ${ }^{-1}$ made it possible to obtain higher values in relation to the control. In addition, the productivity obtained in the highest dose of the biostimulant was the one that provided the greatest increase in grain productivity in relation to the control (9.5\%). This increase is attributed to the increase in grain mass with the increase in the doses of the biostimulant (Figure 3 ). In this case, values of this component of soybean yield were higher in relation to the control from the dose of $0.13 \mathrm{~L} 100 \mathrm{~kg}_{\text {of seeds }}{ }^{-1}$. On the other hand, the other agronomic characteristics were not influenced by the doses of the biostimulant (Table 3).

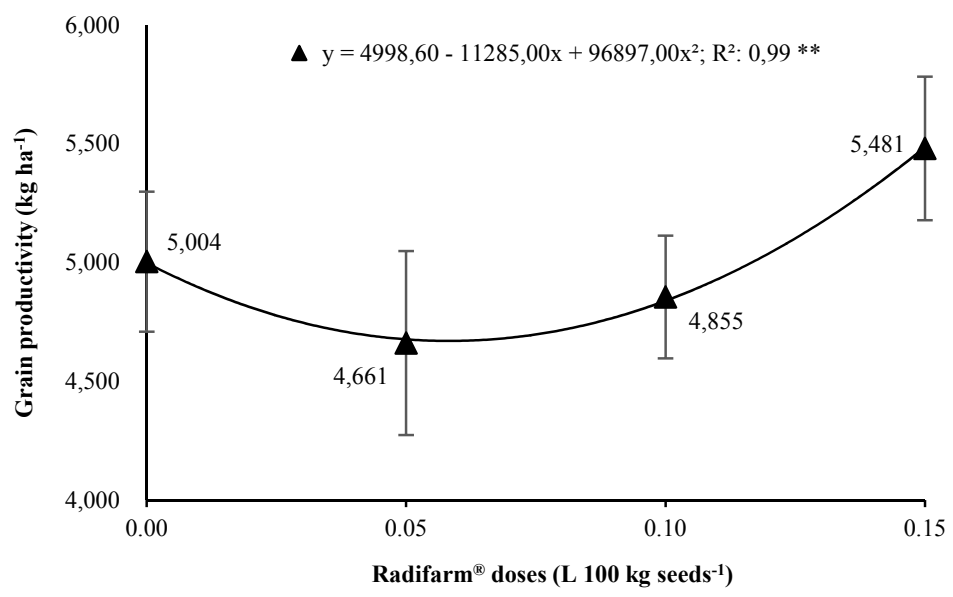

Figure 2. Polynomial regression of grain yield as a function of the doses of an algae extract based biostimulant in the treatment of soybean seeds. Montividiu-GO, 2016/17 harvest 


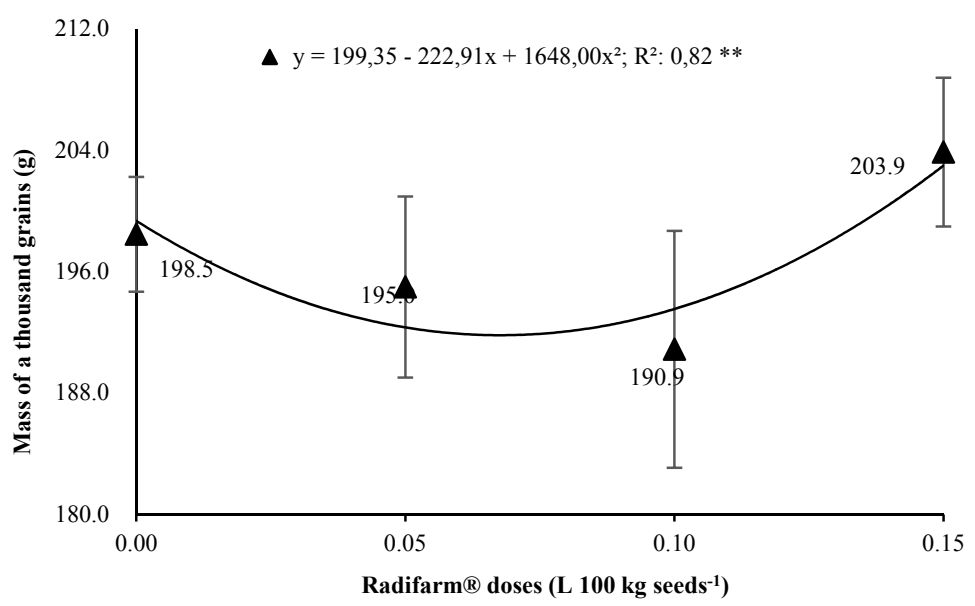

Figure 3. Polynomial regression of the mass of a thousand grains as a function of the doses of a biostimulant based on algae extract in the treatment of soybean seeds. Montividiu-GO, 2016/17 harvest

Despite the increase in the cost of application with the increase in product doses, the highest profitability values were observed in the highest dose (Figure 4). This result, as well as that of grain productivity, indicates the need to evaluate the agronomic performance of soybeans for doses above $0.15 \mathrm{~L} 100 \mathrm{~kg}$ seeds ${ }^{-1}$.

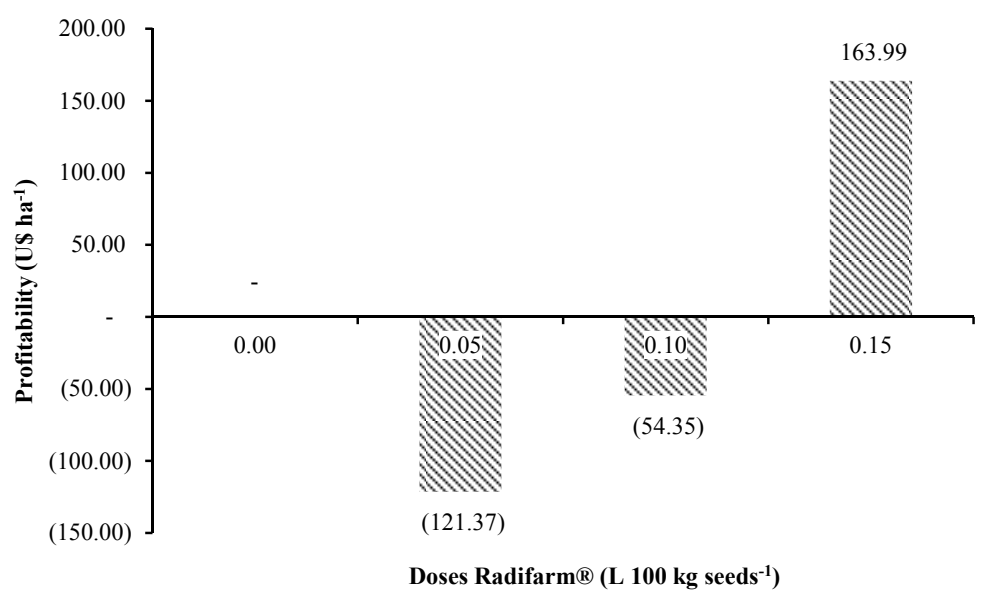

Figure 4. Average profitability values as a function of the doses of algae extract based on the treatment of soybean seeds. Montividiu-GO, 2016/17 harvest

\subsection{Harvest $2017 / 18$}

In the second year testing, the results allowed the verification of the effects of the biostimulant doses for the variables mass of a thousand grains, number of pods on the secondary stems and total and plant height (Table 4). 
Table 4. Summary of the analysis of variance and average values of grain yield (GY), thousand grain mass (TGM), number of grains per plant (NGP), pods on the main branch (PMB), secondary (PSB) and total (PT), number of branches (NB), population (Pop), plant height (PH) and insertion of the first pod (IFP) of the soybean seed treatment trial with algae extract biostimulant. Montividiu-GO, 2017/18 harvest

\begin{tabular}{|c|c|c|c|c|c|c|c|}
\hline Variation sources & GL & GY $\left(\mathrm{kg} \mathrm{ha}^{-1}\right)$ & TMG (g) & NGP & PMB & PSB & $\mathrm{PT}$ \\
\hline Blocs & 5 & $\mathrm{~ns}$ & $\mathrm{~ns}$ & ns & ns & $*$ & $\mathrm{~ns}$ \\
\hline Treatments & 3 & $\mathrm{~ns}$ & $*$ & $\mathrm{~ns}$ & ns & $*$ & $*$ \\
\hline Variation Coef. (\%) & & 5.69 & 2.44 & 9.06 & 16.62 & 22.47 & 13.18 \\
\hline Means & & 4.632 & 195.8 & 59.0 & 20.0 & 13.0 & 33.0 \\
\hline Reg. Linear & 1 & $\mathrm{n}^{\mathrm{n}}\left(\mathrm{R}^{2} 0.00\right)$ & $\mathrm{ns}\left(\mathrm{R}^{2} 0.41\right)$ & $\mathrm{ns}\left(\mathrm{R}^{2} 0.23\right)$ & ${ }^{n}\left(R^{2} 0.15\right)$ & $\mathrm{ns}\left(\mathrm{R}^{2} 0.02\right)$ & $\mathrm{ns}^{-}\left(\mathrm{R}^{2} 0.08\right)$ \\
\hline Reg. Quadratic & 1 & ${ }^{n s}\left(R^{2} 0.64\right)$ & ${ }^{\mathrm{ns}}\left(\mathrm{R}^{2} 0.74\right)$ & ${ }^{\mathrm{ns}}\left(\mathrm{R}^{2} 0.23\right)$ & ${ }^{n s}\left(R^{2} 0.44\right)$ & $*\left(\mathrm{R}^{2} 0.97\right)$ & $*\left(\mathrm{R}^{2} 0.79\right)$ \\
\hline Variation sources & GL & NB & \multicolumn{2}{|c|}{ Pop (plants ha ${ }^{-1}$ ) } & $\mathrm{PH}(\mathrm{cm})$ & \multicolumn{2}{|c|}{$\operatorname{IFP}(\mathrm{cm})$} \\
\hline Blocs & 5 & * & \multicolumn{2}{|c|}{ ns } & ns & \multicolumn{2}{|c|}{$\mathrm{ns}$} \\
\hline Treatments & 3 & $\mathrm{~ns}$ & \multicolumn{2}{|l|}{ ns } & $*$ & \multicolumn{2}{|l|}{ ns } \\
\hline Variation Coef. (\%) & & 10.86 & \multicolumn{2}{|l|}{7.43} & 6.17 & \multicolumn{2}{|l|}{12.89} \\
\hline Means & & 4.0 & \multicolumn{2}{|c|}{406.250} & 78.3 & \multicolumn{2}{|l|}{13.4} \\
\hline Reg. Linear & 1 & $\mathrm{n}^{2}\left(\mathrm{R}^{2} 0.35\right)$ & \multicolumn{2}{|c|}{${ }^{n}\left(R^{2} 0.34\right)$} & $*\left(\mathrm{R}^{2} 0.26\right)$ & \multicolumn{2}{|c|}{ ns $\left(R^{2} 0.43\right)$} \\
\hline Reg. Quadratic & 1 & ${ }^{\mathrm{ns}}\left(\mathrm{R}^{2} 1.00\right)$ & \multicolumn{2}{|c|}{${ }^{\mathrm{ns}}\left(\mathrm{R}^{2} 0.53\right)$} & $*\left(\mathrm{R}^{2} 0.72\right)$ & \multicolumn{2}{|c|}{${ }^{\mathrm{ns}}\left(\mathrm{R}^{2} 0.54\right)$} \\
\hline
\end{tabular}

Note. ${ }^{*}$ and ns: significant at 5\% probability and not significant, respectively, by the F test. GL: degrees of freedom.

Despite the effects of the doses of the biostimulant on the mass of a thousand grains in both harvests, it was not possible to adjust a statistical model in the second harvest (Figure 5). Even so, it was found that the values obtained for the mass of a thousand grains with the use of the biostimulant were higher in relation to the control. Dosing effects were also observed for other agronomic characteristics, with emphasis on the increase in the number of pods on the secondary stems and of total pods (Figure 6).

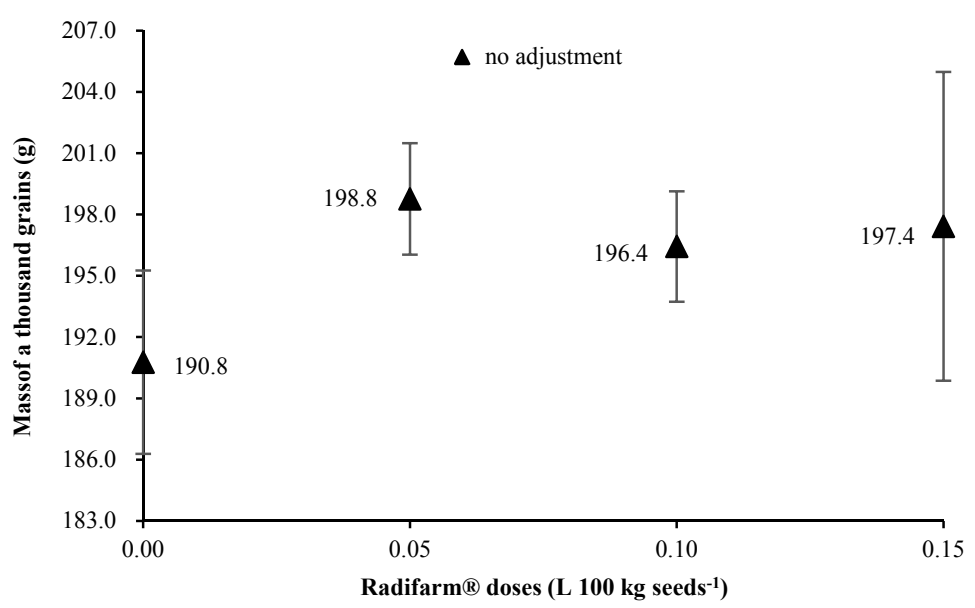

Figure 5. Polynomial regression of the mass of a thousand grains as a function of the doses of a biostimulant based on algae extract in the treatment of soybean seeds. Montividiu-GO, 2017/18 harvest 


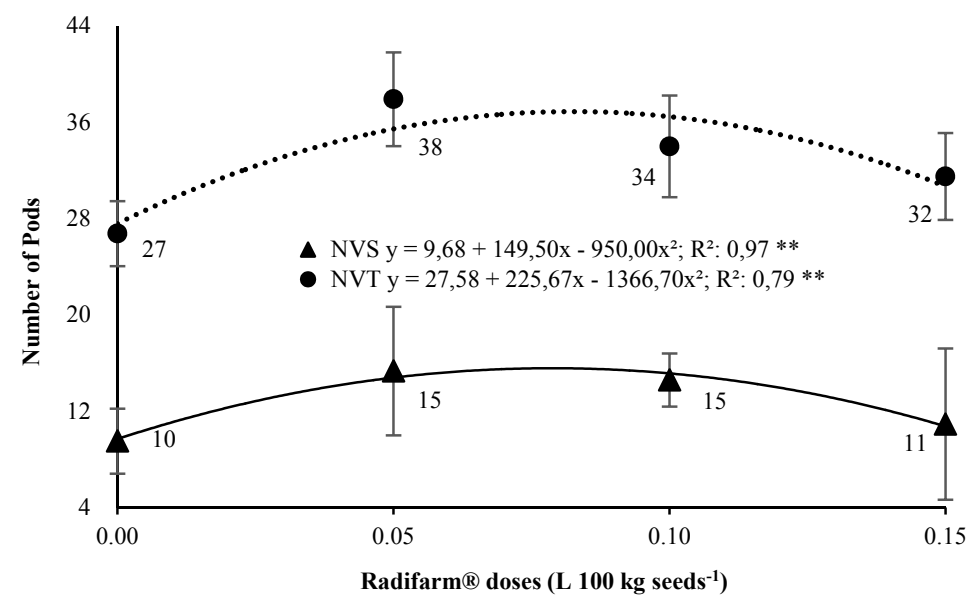

Figure 6. Polynomial regression of the number of pods on the secondary (NVS) and total (NVT) stems as a function of the doses of an algae extract biostimulant in the treatment of soybean seeds.

Montividiu-GO, 2017/18 harvest

Similarly, increasing the dose of the biostimulant to $0.09 \mathrm{~L} 100 \mathrm{~kg} \mathrm{seeds}^{-1}$ provided greater plant height (Figure 7). This effect may be related to the presence of hormonal precursors from A. nodosum extracts present in the biostimulant, in which they act in the increase of cell expansion and growth. On the other hand, doses above 0.09 $\mathrm{L} 100 \mathrm{~kg} \mathrm{seeds}^{-1}$ caused a reduction in the size of the plants, but with values higher than the control.

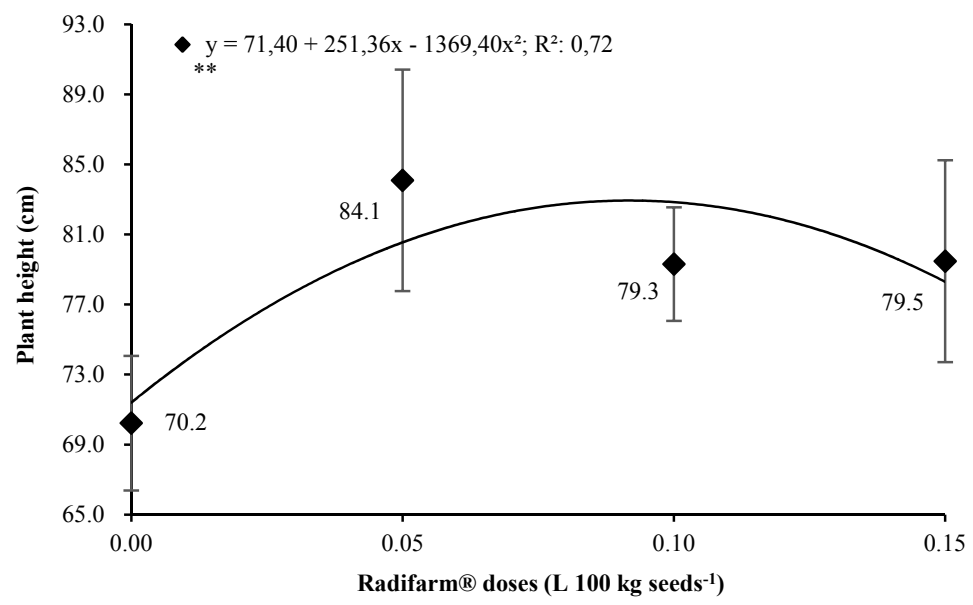

Figure 7. Polynomial regression of plant height as a function of doses of an algae extract biostimulant in the treatment of soybean seeds. Montividiu-GO, 2017/18 harvest

\section{Discussion}

\subsection{Harvest 2016/17}

As observed by Carvalho (2013), increasing doses of biostimulant in seed treatment influenced the components of soybean productivity. The increase in grain productivity due to the increase in biostimulant doses is related to the action of organic compounds present in the product, as previously highlighted, in which they stimulate the plant's metabolic processes (Araújo, 2016; Hidangmayum \& Sharma, 2017; Kocira et al., 2018). In addition, the product provides an increase in the development of the seedling root system, attributed to the presence of analogues to phytohormones and hormonal precursors (Petrozza et al., 2013). This effect allows for an increase in the absorption of water and nutrients at the beginning of seedling development, which favors grain filling (Colombi et al., 2017) in advanced stages of soy maturation, as was observed in the work.

On the other hand, it is also necessary to highlight the importance of the presence of potassium in the composition of the biostimulant. This element is responsible for acting on the enzymatic activation of various physiological processes of the plant, in addition to the transport and partitioning of photoassimilates in the 
phloem (Marschner, 2012). The presence of the element in question may also have contributed to the increase in grain filling, especially in treatments with higher doses of the biostimulant. However, it is necessary to reiterate that the stimulating effect of products derived from algae extract is not attributed only to the presence of a specific compound, but to the synergism between the organic compounds present in the product formulation, combining the presence of nutrients (Wally et al., 2013; Tandon \& Dubey, 2015).

\subsection{Harvest $2017 / 18$}

The different results of the effects of doses on the characteristics evaluated between harvests are probably attributed to differences in climatic conditions (Figure 1).

In the second harvest, the greatest volume and uniformity in the distribution of rain is noticeable, especially in December (Figure 1), a period in which the plants were at the beginning of pod formation. Therefore, greater availability of rainfall is essential when soybean plants are then in the reproductive phase. In these conditions, the lack of water in the soil, common for short dry-spells in the region, drastically affects grain filling (Zanon et al., 2018), thus reducing crop productivity.

Similarly, Albrecht et al. (2011) observed effects on the grain yield of a synthetic bioregulator, used in the treatment of soybean seeds, only in conditions of less precipitation. This may be related to the ability of biostimulants to increase plants tolerance to water stress (Santaniello et al., 2017). Consequently, there is an increase in the activity levels of certain antioxidant enzymes, such as superoxide dismutase, ascorbate peroxidase and catalase (Zhang \& Ervin, 2004; Santaniello et al., 2017). Since the biostimulant used at work potentiates the stimulation of root production (Petrozza et al., 2013), consequently there is a greater absorption of water and nutrients by the plant. Therefore, in this situation it is possible that in conditions of less rainfall or irregular rainfall distribution, it is more common to find the beneficial effects of the product for grain productivity in soybean culture.

The hormonal balance in the plant, in which higher doses of the biostimulant can induce greater root growth instead of aerial part in the initial stages of development, as previously reported, may have been the main cause of the reduction in the size of soybean plants. This leads to the belief that changes in the concentration of phytohormones in the plant can alter cell development and expansion, causing the plant to develop more roots than shoots (Taiz et al., 2015).

Often the reduction in soybean plant size, as seen from the dose of $0.09 \mathrm{~L} 100 \mathrm{~kg} \mathrm{seeds}^{-1}$, is advantageous for soybean cultivation, even though there is no increase in grain productivity. Plants of shorter height are less susceptible to lodging, and sometimes have a greater number of nodes, which in turn provides greater grain yield (Brush \& Karnani, 1996), which was not observed in the study.

Although there was no effect of the biostimulant on grain productivity in the $2017 / 18$ crop, the use of the highest dose was the one that provided the greatest economic profitability (Figure 8). Associated with the results of the previous harvest, it is possible to infer that seed treatment with the dose of $0.15 \mathrm{~L} 100 \mathrm{~kg}$ seeds ${ }^{-1} \mathrm{can}^{\mathrm{be}}$ considered as an interesting practice when profitability increases are desired in the cultivation of soybeans in Cerrado. In addition, this fact is more evident mainly in years with less rainfall distribution, especially when plants are at the beginning of the reproductive phase. Thus, biostimulant use in the aforementioned dose presents itself as having the greatest potential for the soybean seed treatment aiming at greater productive stability of the crop. 


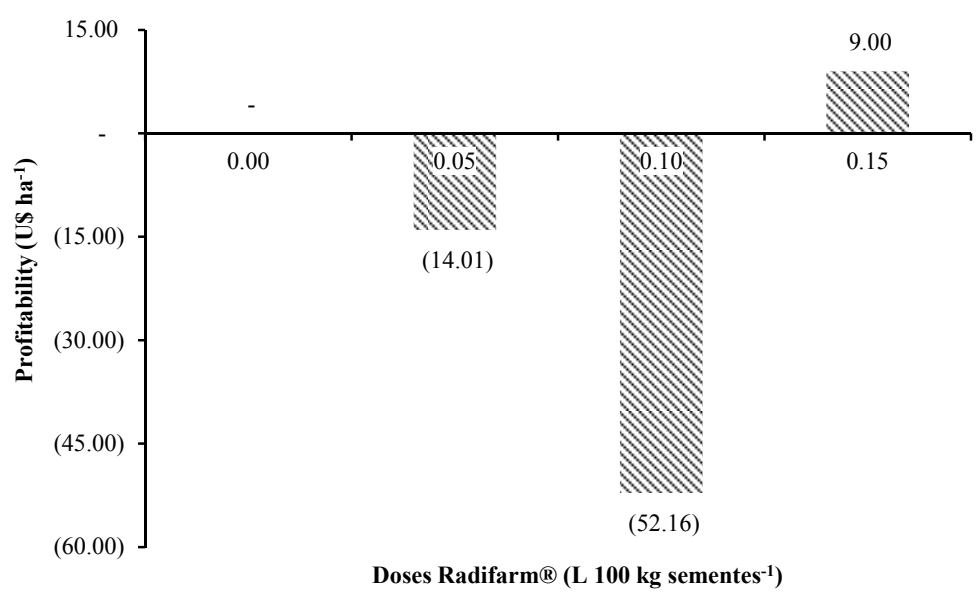

Figure 8. Average profitability values as a function of the doses of an algae extract based biostimulant in the treatment of soybean seeds. Montividiu-GO, 2017/18 harvest

\section{Conclusions}

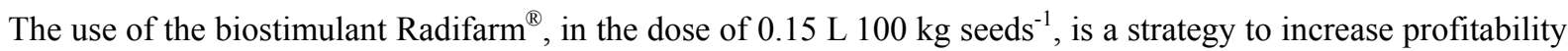
of soybean cultivated in Cerrado, with greater economic return in years of lower rainfall.

\section{References}

Albrecht, L. P., Braccini, A. L., Scapim, C. A.,Ávila, M. R., Albrecht, A. J. P., \& Ricci, T. T. (2011). Manejo de biorregulador nos componentes de produção e desempenho das plantas de soja. Bioscience Journal, 27, 865-876. Retrieved from http://www.seer.ufu.br/index.php/biosciencejournal/article/view/7486

Andrade, C. L. L., Silva, A. G., Braz, G. B. P., Oliveira, J. R. S., \& Simon, G. A. (2020). Performance of soybeans with the application of glyphosate formulations in biostimulant association. Revista Caatinga, 33(2), 371-383. https://doi.org/10.1590/1983-21252020v33n210rc

Araújo, D. K. (2016). Extratos de Ascophyllum nodosum no tratamento de sementes de milho e soja: avaliações fisiológicas e moleculares (Doctoral dissertation, Escola Superior de Agricultura "Luiz de Queiroz", Piracicaba). https://doi.org/10.11606/T.11.2016.tde-07062016-155617

Brush, T., \& Karnani, A. (1996). Impact of plant size and focus on productivity: An empirical study. Management Science, 42(7), 1065-1081. https://pubsonline.informs.org/doi/abs/10.1287/mnsc.42.7.1065

Carvalho, M. E. (2013). Efeitos do extrato de Ascophyllum nodosum sobre o desenvolvimento e produção de cultivos. Escola Superior de Agricultura "Luiz de Queiroz", Piracicaba. https://doi.org/10.11606/D.11.2013. tde-13032013-133345

Colombi, T., Braun, S., Keller, T., \& Walter, A. (2017). Artificial macropores attract crop roots and enhance plant productivity on compacted soils. Science of the Total Environment, 574, 283-1293. https://doi.org/10.1016/ j.scitotenv.2016.07.194

Contiero, R. L. D. F., Biffe, J., Constantin, R. S., Oliveira, J., Braz, G. B. P., Lucio, F. R., \& Schleier III, J. J. (2016). Effects of nozzle types and 2,4-D formulations on spray deposition. Journal of Environmental Science and Health. Part B: Pesticides, Food Contaminants, and Agricultural Wastes, 51(12), 1-6. https://doi.org/10.1080/03601234.2016.1241640

Craigie, J. S. (2011). Seaweed extract stimuli in plant science and agriculture. Journal of Applied Phycology, 23(3), 371-393. https://doi.org/10.1007/s10811-010-9560-4

EMBRAPA (Empresa Brasileira de Pesquisa Agropecuária). (2017). Análise da área, produção e produtividade da soja no Brasil em duas décadas (1997-2016). Boletim de Pesquisa e Desenvolvimento. Londrina, Brazil. Retrieved from http://ainfo.cnptia.embrapa.br/digital/bitstream/item/156652/1/Boletim-de-PD-11.pdf

Ferreira, C. J. B., Tormena, C. A., Severiano, E. C., Zotarelli, E. L., \& Betioli, J. (2020). Soil compaction influences soil physical quality and soybean yield under long-term no-tillage. Archives of Agronomy and Soil Science, 66(2), 1-14. https://doi.org/10.1080/03650340.2020.1733535 
Hidangmayum, A., \& Sharma, R. (2017). Effect of different concentrations of commercial seaweed liquid extract of Ascophyllum nodosum as a plant bio stimulant on growth, yield and biochemical constituents of onion (Allium cepa L.). J. Pharmacogn. Phytochem., 6(4), 658-663. Retrieved from http://www.phytojournal.com/ archives/2017/vol6issue4/PartJ/6-4-99-800.pdf

Kocira, S., Szparaga, A., Kocira, A., Czerwińska, E., Wójtowicz, A., Bronowicka-Mielniczuk, U., ... Findura, P. (2018). Modeling biometric traits, yield and nutritional and antioxidant properties of seeds of three soybean cultivars through the application of biostimulant containing seaweed and amino acids. Frontiers in Plant Science, 9, 388. https://doi.org/10.3389/fpls.2018.00388

Marschner, P. (2012). Mineral Nutrition of Higher Plants. School of Agriculture, Food and Wine, The University of Adelaide, Australia. https://doi.org/10.1016/C2009-0-63043-9

Petrozza, A., Summerer, S., Di Tommaso, G., Di Tommaso, D., \& Piaggesi, Y. (2013). Evaluation of the effect of Radifarm ${ }^{\circledR}$ treatment on the morpho-physiological características of root systems via image analysis (pp. 149-153). I World Congress on the Use of Biostimulants in Agriculture, Leuven, Belgium. https://doi.org/10.17660/ActaHortic.2013.1009.18

Ribeiro, A. C., Guimarães, P. T. P., \& Alvarez, V. H. (1999). Recomendação para o uso de corretivos e fertilizantes em Minas Gerais— $5^{a}$ aproximação. Viçosa Federal University, Viçosa, MG.

Santaniello, A., Scartazza, A., Gresta, F., Loreti, E., Biasone, A., Di Tommaso, D., ... Perata, P. (2017). Ascophyllum nodosum seaweed extract alleviates drought stress in arabidopsis by affecting photosynthetic performance and related gene expression. Frontiers in Plant Science, 8, 1362. https://doi.org/10.3389/ fpls.2017.01362

Santini, J. M. K., Perin, A., Santos, C. G., Ferreira, A. C., \& Salib, G. C. (2015). Viabilidade técnico-econômica do uso de bioestimulantes em semente de soja. Tecnologia \& Ciência Agropecuária, 9, 57-62. Retrieved from https://zeoserver.pb.gov.br/gestaounificada/gu/emepa/publicacoes/revista-2/volume-9-numero-1-marc o-2015/tca9107.pdf/@download/file/tca9107.pdf

Sharma, H. S. S., Fleming, C., Selby, C., Rao, J. R., \& Martin, T. (2014). Plant biostimulants: a review on the processing of macroalgae and use of extracts for crop management to reduce abiotic and biotic stresses. Journal of Applied Phycology, 26(1), 465-490. https://doi.org/10.1007/s10811-013-0101-9

Taiz, L., Zeiger, E., Møller, I. M., \& Murphy, A. (2015). Plant physiology and development (6th ed.). Sinauer Associates Publishers, Sunderland, Massachusetts.

Tandon, S., \& Dubey, A. (2015). Effects of Biozyme (Ascophyllum nodosum) biostimulant on growth and development of soybean [Glycine $\max (\mathrm{L}$.$) Merill]. Communications in Soil Science and Plant Analysis,$ 46(7), 845-858. https://doi.org/10.1080/00103624.2015.1011749

VALAGRO. (2018). Bioestimulantes. Retrieved from Retrieved from http://www.valagro.com/brazil/pt/produtos/ farm/bioestimulante/radifarm

Wally, O. S. D., Critchley, A. T., Hiltz, D., Craigie, J. S., Han, X., Zaharia, L. I., ... Prithiviraj, B. (2013). Regulation of phytohormone biosynthesis and accumulation in Arabidopsis following treatment with commercial extract from the marine macroalga Ascophyllum nodosum. Journal of Plant Growth Regulation, 32(2), 324-339. https://doi.org/10.1007/s00344-012-9301-9

Yakhin, O. I., Lubyanov, A. A., Yakhin, I. A., \& Brown, P. H. (2017). Biostimulants in plant science: a global perspective. Frontiers in Plant Science, 7, 2049. https://doi.org/10.3389/fpls.2016.02049

Zanon, A. J., Silva, R. M., Tagliapietra, L. E., Cera, C. J., Bexaira, P. K., Richter, G. L., ... Streck, N. A. (2018). Ecofisiología da soja: Visando altas produtividades (1st ed.). Santa María, Brazil.

Zhang, X., \& Ervin, E. (2004). Cytokinin-containing seaweed and humic acid extracts associated with creeping bentgrass leaf cytokinins and drought resistance. Crop Science, 44(5), 1737-1745. https://doi.org/10.2135/ cropsci2004.1737

\section{Copyrights}

Copyright for this article is retained by the author(s), with first publication rights granted to the journal.

This is an open-access article distributed under the terms and conditions of the Creative Commons Attribution license (http://creativecommons.org/licenses/by/4.0/). 